BIBLIOTIKA : Jurnal Kajian Perpustakaan dan Informasi

Volume 2 Nomor 1, 2018

Journal homepage : http://journal2.um.ac.id/index.php/bibliotika

\title{
Penilaian kualitas informasi sebagai bentuk sikap tabayyun ketika menerima informasi di sosial media dan internet
}

\author{
Muhammad Usman Noor \\ Program Studi Manajemen Informasi dan Dokumen, Program Vokasi, Universitas Indonesia
}

\begin{tabular}{ll}
\hline A R T I C L E I N F O & A B S T R A C T \\
\cline { 3 - 3 } $\begin{array}{l}\text { Keyword: } \\
\text { kualitas informasi, } \\
\text { hoax, } \\
\text { tabayyun }\end{array}$ & $\begin{array}{l}\text { Tujuan penelitian ini untuk mendeskripsikan kemampuan memilah informasi dan menilai } \\
\text { kualitas informasi. Metode yang digunakan dalam penulisan ini adalah studi literatur. Hasil } \\
\text { dari penulisan ini adalah bagaimana sikap tabayyun dipraktikan dalam situasi praktis. } \\
\text { Metode penilaian informasi yang berkualitas secara ringkas dapat dilihat dari tiga aspek } \\
\text { utama. Reputasi penanggung jawab isi informasi, relevansi isi informasi, dan representasi } \\
\text { informasi. }\end{array}$ \\
\hline
\end{tabular}

\section{PENDAHULUAN}

Era informasi menjadikan kebutuhan akan informasi menjadi lebih tinggi. Menjadikan kemampuan mencari informasi salah satu kompetensi yang dibutuhkan untuk membantu menyelesaikan masalah terkait informasi. Dalam perkembangan akses internet, terdapat pergeseran jika dulu orang melakukan aktivitas browsing internet melalui komputer namun kini aktivitas browsing lebih didominasi oleh penggunaan gawai atau ponsel pintar. Data dari Asosiasi Penyelenggara Jasa Internet Indonesia(APJII) pengguna internet hingga tahun 2016 mencapai 132,7 Juta orang. Dari jumlah tersebut 47,6\% mengakses internet menggunakan gawai atau ponsel pintar. Dari seluruh pengguna internet di Indonesia, masih dari data yang sama, perangkat yang digunakan untuk browsing internet adalah ponsel pintar dengan jumlah mencapai 67,8\%. Sehingga dapat dikatakan lebih banyak menggunakan ponsel pintarnya dalam mengakses internet.

Kini informasi sudah tidak lagi dicari, namun hadir dengan sendirinya bahkan dengan jumlah yang banyak melalui gawai-gawai atau ponsel pintar. Dari data APJII menunjukkan pengakses internet di Indonesia didominasi akses menuju sosial media dengan rasio lebih dari 97,4\% pengguna internet di Indonesia dan hanya $13,6 \%$ yang mengunjungi situs pendidikan.

Sehingga dapat dikatakan masyarakat Indonesia lebih banyak mendapatkan paparan informasi dari sosial media. Sosial media yang populer di Indonesia antara lain facebook, twitter dan instagram . Selain sosial media, aplikasi chatting yang populer di Indonesia seperti Whatssap dan LINE juga menjadi saluran masuknya informasi ke masyarakat tanpa harus pengguna tersebut mencari. Informasi yang masuk dari aplikasi chatting atau sosial media seringkali masuk tanpa pengguna internet tersebut mencari. Di aplikasi chatting Whatsapp orang biasanya menerima pesan berantai dari grup-grup yang diikuti. Sedangkan pada aplikasi LINE terdapat fitur LINE today yang berisi rangkuman berita dari berbagai sumber. Hingga tahun 2016 pengguna LINE di Indonesia sudah tercatat sebanyak 90 juta orang(Brilio 2016). Tidak ada data pasti berapa pengguna Whatsapp di Indonesia, namun secara global Whatsapp digunakan lebih dari 900 juta pengguna hingga akhir tahun 2015 (CNNIndonesia, 2015).

Informasi yang diterima pun tidak hanya sekadar dapat dibaca, namun penerima informasi juga bisa langsung menjadi penyebar informasi jika informasi yang dia terima tersebut diteruskan melalui berbagai saluran aplikasi atau sosial media yang ada. Kemudahan tersebut sangat terasa karena setiap

\footnotetext{
"Corresponding author.

E-mail addresses: musmannbox@gmail.com (Muhammad Usman Noor)
}

ISSN : 2579-3802 (Online) - BIBLIOTIKA : Jurnal Kajian Perpustakaan dan Informasi is licensed under Creative Commons AttributionShareAlike 4.0 International License (http://creativecommons.org/licenses/BY/4.0/).

33 | BIBLIOTIKA : Jurnal Kajian Perpustakaan dan Informasi 
sosial media atau aplikasi chatting memberikan fitur untuk meneruskan informasi. Semakin banyak suatu informasi dibagikan maka informasi tersebut berpotensi menjadi viral dan tersebar luas di masyarakat. Sehingga kini kemampuan menyeleksi informasi dan menilai informasi menjadi penting (Hanafiyah, 2018).

Kemudahan berbagi informasi melalui sosial media dan internet di sisi lain membantu siapapun untuk menerima, memberi, atau meneruskan informasi. Namun akibat terlalu bebasnya tersebut pada akhirnya terjadi ledakan informasi yang diantara lebih banyak informasi yang tidak bermanfaat ketimbang bermanfaat. Hal tersebut terjadi karena lemahnya pengawasan dalam penggunaan sosial media dan internet menjadikan siapapun dapat menyebarkan informasi dengan mudah disana. Baik itu informasinya benar ataupun salah. Lebih parahnya lagi, banyak kemudian informasi bohong atau yang dikenal sebagai informasi hoax di masyarakat.

Kondisi di Indonesia terkait penyebaran hoax dilihat dari perkembangannya menunjukkan kenaikan yang signifikan. Berdasarkan data dari Indonesia indicator, terdapat kenaikan jumlah ekspos media terhadap hoax pada semester kedua tahun 2016. Dengan angka, pada semester pertama tahun 2016 tiap bulannya terdapat pemberitaan media terkait hoax sebanyak 340, sedangkan pada semester kedua tahun 2016 angkanya naik menjadi 879 (Infokomputer 2016). Kenaikan tersebut dipicu makin meningkatnya subjek pembahasan informasi hoax, jika dulu berkutat pada fenomena kesehatan, selebriti, atau sosial, kini bergeser ke isu politik dan SARA karena kontestasti politik di Indonesia. Definisi Hoax dalam Merriam-Webster adalah memberikan informasi bohong, fiktif, atau lelucon dengan tujuan agar orang yang menerimanya menjadi percaya dengan berita tersebut. Sehingga masyarakat dituntut memiliki kemampuan memilah dan menilai kualitas dari informasi ketika mendapatkan sebuah berita atau informasi.

Dalam konteks ajaran agama Islam, menilai kebenaran suatu informasi atau berita atau yang dikenal dengan istilah sifat tabayyun menjadi sesuatu yang penting. Ayat Al-Quran yang masyur membahas kewajiban muslim untuk bertabayyun adalah Al Hujurat ayat 6

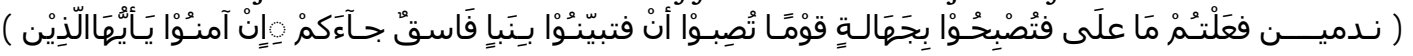

Artinya : "Wahai orang-orang yang beriman, jika datang seorang yang fasik kepadamu membawa berita, maka tangguhkanlah (hingga kamu mengetahui kebenarannya) agar tidak menyebabkan kaum berada dalam kebodohan (kehancuran) sehingga kamu menyesal terhadap apa yang kamu lakukan" (QS.AlHujurat:6).

Ayat ini, menurut banyak ulama, turun menyangkut kasus al-Walid bin Uqbah yang ditugaskan Nabi Muhammad Saw. menuju ke Bani al-Musthalaq untuk memungut zakat namun kemudian al-Walid yang diutus mengira Bani al-Musthalaq akan menyerang Nabi Muhammad. Setelah Nabi Muhammad SAW mendengar hal tersebut Nabi Muhammad mengirimkan utusan untuk menyelediki kebenaran dan tidak mengambil langkah menyerang sebelum persoalannya jelas. Setelah diselidiki ternyata justru Bani alMusthalaq ingin menyambut kedatangan utusan Nabi Muhammad SAW bukan ingin menyerang. Nabi Muhammad SAW melarang kita untuk menyampaikan setiap kabar yang kita dengar sampai kita periksa dahulu, beliau bersabda yang artinya:

“Cukuplah bagi seseorang Kedustaan, ia menyampaikan seluruh apa yang ia dengar..” [HR.Muslim: 1/10, no.5].

Dari riwayat ini menunjukkan bahwasanya Agama Islam melalui firman Allah SWT dan sabda Nabi Muhammad SAW mengajarkan kaum muslimin untuk selalu mengecek berita ketika mendapat informasi. Terlebih jika informasi tersebut didapat dari sumber yang kita tahu itu tidak benar atau kurang jelas kebenarannya. Informasi yang salah yang terus menerus diterima oleh seseorang melalui skema misinformasi akhirnya akan membentuk pemikiran bawah sadar seseorang dan mempengaruhi bagaimana orang tersebut dalam merespon informasi (Meek, Scott et al, 2013, 81-87). Maka efek dari informasi bohong dapat berbahaya jika dilakukan terus menerus dan secara global.

Penyebaran informasi salah dapat menyebabkan keresahan di masyarakat. Hal tersebut membuat pemerintah mengambil langkah terkait penggunaan sosial media dan transaksi elektronik tersebut. Pemerintah mengeluarkan Undang-undang untuk mengendalikan penyebaran berita yang salah. Tertuang dalam Undang-undang 11 tahun 2008 tentang informasi dan transaksi elektronik.

Karakteristik manusia yang suka menyebarkan informasi makin menjadikan informasi bisa menjadi berbahaya jika yang disebarkan adalah informasi bohong atau hoax. Besarnya bahaya yang ditimbulkan akibat penyebaran berita bohong menjadikan pentingnya kemampuan untuk menyaring informasi, tujuannya agar masyarakat tidak cepat mengambil keputusan dari berita yang diterima dan tidak mudah menyebarkan ulang berita apapun yang diterima. Derasnya informasi yang beredar di masyarakat menjadikan pentingnya kemampuan menyaring informasi dan menilai kualitas informasi. Tulisan ini 
ditujukan untuk meningkatkan daya kritis masyarakat terhadap kualitas suatu informasi dan mampu melakukan tabayyun dengan metode menilai kualitas informasi secara praktis. Untuk mengurangi dampak penyebaran informasi bohong, disinformasi, dan hoax di masyarakat. Dan dalam rangka membangun masyarakat yang melek informasi (information literate)

\section{METODE PENELITIAN}

Penelitian ini disusun dengan menggunakan metode kepustakaan atau Library Research. Studi kepustakaan adalah teknik pengumpulan data dengan mengadakan studi penelaahan terhadap buku-buku, literature, catatan, dan laporan yang ada sehingga diperoleh data-data yang diperlukan terkait dengan masalah yang dibahas.(Nazir, M 2003,27)

Data primer yang digunakan dalam penelitian ini adalah hukum positif, hukum agama Islam, dan teori dalam ilmu informasi. Data sekunder yang digunakan adalah buku dan jurnal yang berkaitan dengan tema yang di teliti. Teknik yang digunakan adalah dengan mengumpulkan dokumentasi yang berbentuk catatan-catatan, buku, jurnal, surat kabar dan bahan-bahan tertulis lainnya yang berkaitan dengan topic pembahasan. Teknik analisis data yang digunakan sebagai berikut. Pertama, deskripsi untuk menjelaskan dan mendeskripsikan suatu keadaan, persitiwa, objek apakah orang, atau segala sesuatu yang terkait dengan variable yang bisa dijelaskan.

Penelitian ini menggunakan kajian deskriptif analisis dan kepustakaan. Deskriptif analisis digunakan untuk presentasi objek tentang realitas yang terdapat dalam bidang yang diteliti, metode sistematis dilakukan untuk mendeksripsikan objek selanjutnya melalui data yang terkumpul akan dianalisis. Kepustakaan akan digali data yang sesuai dengan kebutuhan penelitian.

\section{HASIL PENELITIAN}

Diseminasi informasi yang salah dapat dibagi menjadi dua, yaitu misinformasi dan disinformasi. Misinformasi adalah informasi salah yang sengaja disebarkan agar yang menerima tertipu atau menganggap informasi salah itu adalah kebenaran. Sedangan disinformasi adalah informasi salah yang tidak sengaja tersebar. Dua hal ini meskipun niatnya berbeda namun efeknya bisa sama, yaitu sama-sama menyebarkan berita bohong dan dapat meresahkan.

Kemampuan untuk menggunakan informasi di internet dikenal dengan istilah Web literacy atau literasi web. Literasi web adalah kompetensi yang dibutuhkan untuk membaca, menulis, dan berpartisipasi di internet. Namun kemampuan tersebut baru sebatas menggunakan, namun belum sampai tingkat menilai kualitas informasi di web.

Umat Muslim dalam menerima informasi telah diperintahkan untuk bersikap tabayyun. Perintah untuk bersikap tabayyun terdapat dalam surat al-Hujurat ayat 6. Makna tabayyun sendiri banyak ditafsirkan oleh berbagai ahli tafsir. Salah satunya Imam Asy Syaukani menafsirkan sebagai berikut "Yang dimaksud dengan Tabayyun adalah memeriksa dengan Teliti dan yg dimaksud dengan Tatsabbut adalah berhati-hati dan tidak tergesa-gesa, melihat dengan ke-Ilmuan dalam sebuah Peristiwa dan Kabar yg dating sampai Menjadi Jelas dan Terang Baginya..” (Asy-Syaukani 2007). Tafsir tersebut diperkuat dengan tafsir dari Aidh Al-Qarni dalam Tafsir Al-Muyassarnya menafsirkan Surat Al-Hujurat ayat 6 sebagai berikut "Wahai orang-orang yang beriman kepada Allah SWT. Dan Rasulnya, apabila orang yang fasik terhadap agamanya menyampaikan berita kepada kalian maka telitilah kebenaran itu. Janganlah kalian mempercayainya sebelum kalian mengetahui kebenarannya dan memastikan kejujurannya. Sebab, dikhawatirkan kalian akan menyakiti seseorang yang tidak bersalah, hanya karena berita orang fasik, lantas kalian menyesal karena terlanjur menyakiti orang yang tidak bersalah".

Lebih lanjut, hasil dari penelitian Dina Nasicha (2016) mengenai tafsir Tabayyun menjelaskan makna tabayyun dengan lebih ringkas melalui komparasi tafsir antara Tafsir Al Muyassar dan Tafsir Al MIsbah. Dalam menafsirkan ayat tentang Tabayyun menurut M. Quraish Shihab dan Aidh al-Qarni mereka sama-sama mengartikan Fatabayyanu sebagai makna teliti dalam menerima berita atau informasi yang disebarkan oleh orang fasik. Sehingga dapat disimpulkan bahwa Tabayyun adalah sikap tidak tergesa-gesa dan meneliti terlebih dahulu ketika menerima atau berita atau informasi dari orang fasik. Orang fasik sendiri secara sederhana diartikan sebagai orang yang telah keluar dari ketaatan kepada Allah (Imam Abu Ja'far At-Thabari dalam Ammi Nur baits ).

Maka dari makna tabayyun di atas jika dimasukkan dalam konteks menerima informasi di sosial media atau internet adalah, tidak tergesa-gesa dalam mengambil keputusan apakah informasi tersebut benar atau salah. Selain itu sikap tidak tergesa-gesa menghindarkan dari kemungkinan langsung meneruskan informasi tersebut ke rekan atau grup di sosial media. Kemudian langkah yang dapat dilakukan ketika menerima informasi adalah mencari sumber lain yang terkait dengan informasi yang diterima, sehingga bisa menilai apakah informasi tersebut benar atau salah. Selain itu sikap yang 
ditonjolkan dalam tafsir diatas ketika menerima informasi di sosial media atau internet maka mengecek siapa yang membawa informasi tersebut, apakah dari sumber yang individu atau organisasi yang validitasnya jelas atau tidak jelas. Sehingga terdapat tiga langkah sederhana yang ditarik dari perintah bersikap tabayyun, pertama, tidak tergesa-gesar, kedua, mencari informasi silang terkait informasi yang diterima. Ketiga mengecek siapa yang menbuat dan menyebarkan informasi tersebut.

\section{PEMBAHASAN}

1. Menilai Kualitas Informasi

Selain memiliki sikap tabayyun, umat muslim dianjurkan untuk memiliki kemampuan menilai kualitas informasi sehingga lebih dapat mengidentifikasi mana informasi yang salah atau benar. Kemampuan menilai Kualitas informasi (information quality) menjadi hal yang penting, karena Informasi yang benar sekalipun belum tentu memiliki nilai informasi yang bermanfaat bagi dirinya atau orang lain. Apalagi jika informasi tersebut salah atau bohong. Informasi bohong banyak memberi efek buruk hingga sampai ke pola pikir yang menerimanya. Banyaknya informasi bohong bisa menggiring orang yang menerima menjadi percaya pada informasi bohong tersebut.

Selain informasi benar atau salah, terdapat juga jenis informasi yang lain dilihat dari sifat isi informasinya. Secara mendasar sifat informasi dapat dibagi menjadi 5 jenis sifat informasi, antara lain:

1. Informasi Benar atau salah, Berhubungan dengan kebenaran terhadap kenyataan

2. Informasi Baru, Informasi benar-benar baru bagi penerima.

3. Informasi Tambahan, Informasi dapat memperbaharui/memberikan perubahan terhadap informasi yang telah ada.

4. Informasi Korektif, Digunakan untuk melakukan koreksi terhadap informasi sebelumnya yang salah 5. Informasi Penegas, Dapat mempertegas informasi yang telah ada, sehingga keyakinan terhadap informasi semakin meningkat. (Davis 1991,29)

Proses menilai kualitas informasi adalah proses yang kompleks. Kriteria dasar dalam menilai kualitas informasi seringkali penerima informasi kesulitan dalam menelusur dari mana informasi itu didapatkan. Terlebih informasi yang diterima di aplikasi sosial media dan chatting seperti whatssap, line, yang seringkali tidak ada sumber atau siapa penulis pertamanya. Sehingga hanya diketahui siapa teman atau saudara yang menyebarkan informasi tersebut.

Telah banyak pakar di bidang ilmu informasi yang menjelaskan cara menilai kualitas informasi. Salah satunya adalah Wang dan Strong yang membagi penilaian kualitas informasi ke dalam beberapa bagian oleh, antara lain Intrinsik, didalamnya menilai akurasi, objektivitas, validasi isi informasi dan reputasi dari sumber informasi. Kontekstual yaitu melihat relevansi, nilai tambah, kelengkapan informasi. Representasi, melihat informasi tersebut dari tampilan, format dan kompatibilitas dengan alat pembaca. Aksesbilitas, kemudahan mengakses serta keamanan dari informasi. Relevansi. Nilai tambah, tepat waktu (timeliness), kelengkapan, banyaknya informasi. Suryana dalam Koswara $(1998,102)$ menambahkan bawah nilai informasi dapat ditentukan dari cakupan dari isi informasi tersebut, kecermatan pembuatan dan format penyajian informasi, kemutakhiran informasi, kredibilitas informasi, dan frekuensi penyajian informasi tersebut. Dari dua pendapat tersebut kredibilitas pembuat informasi, kelengkapan informasi, keterbaruan informasi, dan penyajian informasi menjadi perhatian penting dalam menilai kualitas informasi.

Secara khusus Tseng and FOgg (1999 dalam Zmming Liu 2003) mengemukakan kriteria dalam menilai sumber informasi yang terdapat di internet dapat dilihat dari Presumed credibility, informasinya di tampilkan pada website yang terlihat kompeten dan ditulis dalam bahasa yang jelas. Reputed credibility, penulisnya berafiliasi dari institusi atau badan organisasi yang diakui dan dikenal. Surface credibility, layout dokumen rapih dan tidak asal-asalan. Experienced credibility, isi informasi tersebut sama dengan informasi yang dipublikasikan dalam jurnal tercetak, jika informasinya berupa jurnal.

Kriteria penilian informasi yang didapat dari internet diperkuat oleh pendapat dari Katerattanakul dan Siau tentang dimensi yang dilihat dalam menilai kualitas informasi dari website individual antara lain, Intrinsik, informasi bebas dari kesalahan pengetikan, informasi bisa ditelusur, dan jika terdapat tautan yang relevan. Kontekstual, terdapat informasi mengenai siapa yang bertanggung jawab akan informasi tersebut. Representatif, tampilan dan pemilihan typografi sesuai serta desain yang konsisten. Aksesibilitas, informasi akan lebih bernilai jika memiliki navigasi di laman web tersebut (Lestari, 2017).

Dari pendapat mengenai penilaian informasi di web maka hal yang menjadi penting adalah terdapat informasi yang jelas mengenai siapa yang menulis informasi tersebut. Informasi dapat ditelusur dan informasi disampaikan dengan jelas dan tidak asal-asalan, baik dari sisi bahasa maupun tampilan di web tersebut. Dari berbagai sumber diatas kemudian ada pendapat dari Miller, Holmes yang menguatkan 
berbagai pendapat diatas terkait penilaian informasi, melalui matriks penilaian kualitas informasi sebagai berikut:

1. Penanggung jawab isi Informasi, hal ini disebut juga dengan autoritas, merujuk pada kualitas dari yang mengeluarkan informasi, baik itu badan maupun individu. Kualitas disini menunjukkan reputasi atau tingkat kepercayaan pada author tersebut.

2. $\quad$ Ruang lingkup, merujuk pada sedalam apa informasi tersebut dapat dieksplor.

3. Komposisi dan terorganisasir, sumber informasi tersebut berisi pesan yang jelas dan koheren, memiliki logika yang masuk akal jika dirunut isi informasinya.

4. Objektivitas, informasi bebas dari sesuatu yang bisa menjadi sesuatu yang bias dan bersifat opini bagi siapapun yang menilai. Umumnya berita yang terdapat kata persuasif patut dipertanyakan.

5. Integritas Isi informasi tersebut disampaikan dengan cara yang etis dan sesuai moral. Informasi tersebut utuh, tidak ada yang bolong atau tidak jelas.

6. Komprehensif Informasi tersebut memiliki cakupan yang luas, bisa dieksplorasi, Informasi tersebut terbuka untuk dikaji lebih dalam, Informasi tersebut aman dalam konteks luas, tidak menimbulkan masalah

7. Validitas, Sumber informasi maupun media informasinya merupakan sumber valid, dan dapat dipercaya.

8. Unik, Informasi disini bersifat unik. Isi informasinya intuitif. Informasinya meski dapat diartikan dalam banyak konteks namun dalam lingkup luas tidak menimbulkan kerancuan.

9. $\quad$ Tepat waktu, Informasi tersebut sesuai konteksnya ketika di publikasikan.

10. Reproduktibiltas, Informasi dapat diubah ke berbagai bentuk atau format tanpa mengurangi isi dan nilai dari informasi tersebut.

Dari beberapa sumber diatas terkait penilaian kualitas informasi maka dapat disederhankan menjadi tiga hal yang paling utama dalam menilai kualitas informasi, antara lain reputasi, relevansi, dan presentasi.

Reputasi. penulis informasi atau yang mengeluarkan informasi tersebut jelas dan dapat diverifikasi. Penanggung jawab isi informasi, atau biasa dikenal sebagai penulis, menjadi hal paling esensial. Setiap informasi yang diterima yang paling utama dilihat adalah siapa penanggung jawab isi informasinya, jika suatu informasi tidak ditemukan siapa penanggung jawab isi informasinya maka harus diwaspadai dan lebih baik ditinggalkan. Jika terdapat informasi terkait penanggung jawab isi informasinya hal yang dapat dilakukan adalah mengecek reputasi dari penulis tersebut. Jika memang dia adalah pakar atau ahli di bidang tersebut maka itu menjadi nilai tambah. Seseorang yang terkenal atau memiliki reputasi sekalipun bukan berarti dapat dipercayai begitu saja, jika dia bicara sesuatu yang bukan ranah keahliannya maka sebaiknya kita mencari pendapat dari yang lebih ahli terkait bidang tersebut.

Jika informasi berupa berita atau ilmu pengetahuan maka parameternya pertimbangan penanggung jawab isi informasinya adalah selain penulis adalah siapa yang dia kutip. Jika berita atau teori tersebut dikutip dari badan atau individu yang valid maka informasi tersebut layak digunakan. Sehingga dapat disimpulkan, jika informasi tersebut dikeluarkan oleh individu atau badan yang memiliki reputasi jelas dan memiliki kemampuan di bidang terkait informasi tersebut maka informasi tersebut dapat dipertanggungjawabkan.

Relevansi, informasi dapat ditelusur. Informasi yang berkualitas adalah informasi yang dapat dikonstrusikan menjadi satu kesatuan informasi utuh dari berbagai sumber. Informasi juga dapat dikatakan berkualitas jika memiliki konteks dan tidak berdiri sendiri. Informasi yang tidak dapat ditemukan informasi lain yang relevan serta mendukung kebenarannya maka informasi tersebut patut diwaspadai. Relevansi juga bicara mengenai keterbaruan, informasi yang telah lewat masanya biasanya akan kehilangan konteksnya. Informasi yang telah hilang konteksnya umumnya sudah tidak terlalu bermanfaat. Informasi dapat dikatakan relevan jika informasi tersebut saling mendukung dengan informasi dari sumber lain yang membicarkan hal yang sama. Ciri informasi yang relevan selain itu adalah mudah mencari rujukan terkait. Informasi juga tidak terlalu sempit lingkup cakupannya namun juga tidak terlampau umum. Informasi yang berkualitas umumnya dapat disusun secara logis dan komprehensif dengan beragam sumber informasi lain, sehingga saling menguatkan kebenarannya.

Representasi menjadi salah satu parameter utama dalam penilaian kualitas informasi. Hal-hal yang mencakup dalam representasi adalah penggunaan bahasa, tampilan antarmuka, dan penyajian informasi. Penggunaan bahasa yang jelas, tidak bertele-tele menjadi nilai tambah dalam penilaian kualitas informasi. Informasi yang didalamnya terdapat banyak kalimat yang bersifat persuasif sebaiknya dihindari, karena rentan berupa opini atau pendapat pribadi. Bahasa yang digunakan etis, tidak menyinggung dan sesuai pada moral yang berlaku. 
Tampilan informasi baik itu berupa gambar maupun tulisan ditampilkan secara jelas. Gambar dipilih adalah gambar yang sesuai dengan isi informasi dan terdapat penjelasan terkait gambar tersebut. Informasi yang menyertakan gambar sebagai ilustrasi dan tidak menggambarkan kejadian atau informasi sebenarnya maka diberi keterangan. Jika informasi berupa laman web, maka antar mukanya mudah dipahami dan tidak membingungkan. Pemilihan desain baik itu berupa warna dan pemilihan tipografi memastikan pembaca tidak menemukan kesulitan dalam membacanya, hal tersebut menjadi nilai tambah dalam penilaian kualitas informasi.

\section{Mendistribusikan Kembali Informasi}

Sikap yang dianjurkan pada kaum muslimin ketika menerima informasi adalah bertabayyun, salah satunya dengan cara menilai kualitas informasi yang diterima. Dalam konteks menerima informasi di sosial media atau internet, Tidak hanya menerima, kini penerima informasi juga dapat dengan mudah meneruskan informasi tersebut. Informasi dapat dengan mudah disebarkan kembali ke khalayak dengan fitur yang ada di sosial media atau aplikasi chatting. Sehingga ada tanggung jawab tersendiri terkait informasi yang kembali disebarkan.

Perlu menanamkan pemahaman jika informasi salah disebarkan maka dampaknya bisa berbahaya baik bagi dirinya maupun masyarakat umum. Berita salah yang terlanjur menyebar dan menjadi gagasan di masing-masing pikiran manusia akan sulit dihapus, karena Pikiran mudah sekali dirasuki berbagai macam hal dan informasi. Informasi atau gagasan kemudian menjadi pola pikir dan memori bawah sadar. Kemampuan seseorang menafsir juga dapat berbeda tergantung lingkungan. Dukungan lingkungan membuat tafsiran seseorang terhadap sesuatu, termasuk tafsiran keliru, akan mengendap lama dalam otak sehingga memperkuat dengan tafsiran individu (Kompas 2015).

Dalam fikih, terdapat berbagai aturan dalam mengolah berbagai jenis informasi. Setidaknya, informasi tersebut dapat diklasikasikan dalam tiga bentuk menurut Faris Khoirul Anam, yang pertama kejadian atau peristiwa biasa. Kedua, kejadian yang mengandung unsur kriminalitas, atau berhubungan dengan hak orang lain. Ketiga berita yang menyangkut kepentingan umum, seperti keamanan negara.

Ketika seorang muslim mendapatkan informasi dan berkeinginan menyebarkannya maka ada yang perlu diperhatikan. Hal yang pertama diperhatikan adalah mengecek kebenaran dan kualitas informasi tersebut. Jlka informasi tersebut salah maka dapat dipastikan informasi tersebut tidak boleh disebarkan. JIka informasi tersebut benar maka ada langkah yang dikedepankan menurut Khairul Anam. Hal pertama adalah menilai apakah informasi itu bermanfaat? Informasi terbukti benar, belum menjadi alasan bagi seseorang untuk membagikannya. Dia harus dapat memastikan, apakah informasi itu bermanfaat? Hal ini berdasarkan konsepsi bahwa seorang muslim dalam membuat dan menyebarkan informasi, didasari oleh niat ibadah, berdakwah, dan beramar ma'ruf nahyi munkar.

Meskipun suatu berita benar, namun bila tidak memberikan kemanfaatan untuk orang lain, seorang jurnalis profesi dan jurnalis warga pantang untuk menyebarkannya. Rasulullah SAW bersabda: "Barang siapa beriman ke pada Allah dan hari akhir, katakanlah kebaikan atau diamlah." (HR. Bukhari dan Muslim). Apabila informasi tersebut terbukti benar dan bermanfaat maka sebarkanlah. Dua hal inilah yang menjadi prinsip pembuatan dan penyebaran informasi, yaitu kebenaran dan kemanfaatan berita. Allah SWT berfirman dalam Surat Ali Imran ayat 104 (yang artinya): "Dan hendaklah ada di antara kamu segolongan umat yang menyeru kepada kebajikan, menyuruh kepada yang ma'ruf dan mencegah dari yang munkar; mereka adalah orang-orang yang beruntung.”

Dari sisi hukum positif mengenai penyebaran informasi melaui sosial media atau internet secara umum diatur dalam Pasal 28 Undang-undang 11 tahun 2008 tentang informasi dan transaksi elektronik (19) yang berbunyi:

(1) Setiap Orang dengan sengaja dan tanpa hak menyebarkan berita bohong dan menyesatkan yang mengakibatkan kerugian konsumen dalam Transaksi Elektronik.

(2) Setiap Orang dengan sengaja dan tanpa hak menyebarkan informasi yang ditujukan untuk menimbulkan rasa kebencian atau permusuhan individu dan/atau kelompok masyarakat tertentu berdasarkan atas suku, agama, ras, dan antargolongan (SARA).

Sehingga dari hukum islam dan hukum positif terlihat jelas bahwasanya mengatur distribusi informasi. Jika seseorang tidak yakin akan informasi yang dia terima maka sebaiknya tidak menyebarkan informasi tersebut. Motivasi ingin memberitakan hal yang berpotensi viral, atau menjadi sensasi sebaiknya dihindari. Mengingat dampak penyebaran informasi yang salah dapat sedemikian massif. Berita benar yang tidak berguna pun seringkali akhirnya pembicaraan sehari-hari yang menghabiskan banyak waktu dan tidak bermanfaat. 
Kemudahan dalam menerima informasi dan menyebarkan informasi adalah dua hal yang tidak didapat di generasi-generasi sebelumnya. Kemajuan teknologi informasi harus diimbangi dengan meningkatnya kualitas literasi menggunakan sosial media dan internet di masyarakat jika tidak termakan bahaya informasi bohong atau lebih dikenal dengan hoax. Informasi yang berkualitas secara ringkas dapat dilihat dari tiga aspek utama. Reputasi penanggung jawab isi informasi, relevansi isi informasi, dan representasi informasi. Informasi yang berkualitas biasanya adalah informasi yang benar. Benarnya informasi masih harus dinilai apakah bermanfaat atau tidak, jika tidak bermanfaat maka tidak perlu disebar. Jika dirasa informasi tersebut benar, berkualitas, dan bermanfaat maka boleh disebarkan. Dampak penyebaran informasi hoax dapat dimulai dari individu masing-masing, dimulai dari diri sendiri.

Saran

Ketika menerima informasi maka bagi muslim sikap tabayyun adalah sikap pertama yang dilakukan. Tidak tergesa-gesa mengambil sikap ketika menerima informasi adalah hal yang pertama dilakukan dalam sikap tabayyun. Kemudian sikap seorang muslim ketika menerima informasi adalah melakukan pengecekan terlebih dahulu informasi atau berita tersebut apakah benar atau salah.

\section{DAFTAR RUJUKAN}

Al-Mubarakfuri, Syaikh Shafiyyurrahman dan Tim ahli Tafsir, Al-Mishbaahul Muniir fii Tahdziibi Tafsiri Ibnu Katsiir, Riyadh: Daarus Salam Lin Nasyr Wat Tauzi', 2000, terj. Abu Ihsan al-Atsari. 2011. Shahih Tafsir Ibnu Katsir. Jakarta: Pustaka Ibnu Katsir

Anam, Faris Khoirul. Fikih Informasi Jurnal Islamia Republika. http://www.republika.co.id/berita/koran/islamia/15/04/16/nmw8rl-fikih-informasi (diakses Januari 2017)

Anam, Faris Khoirul. 2009. Fikih Jurnalistik: Etika dan Kebebasan Pers Menurut Islam. Jakarta: Pustaka Al-Kautsar

APJII. Infografis Penetrasi \& Perilaku pengguna internet Indonesia survey 2016. https://apjii.or.id/survei2016/download/ZUHo3mhL12AWzQG0Jg4dYa5OvR8qpl (diakses pada Februari 2017)

Cakrawala, Indah. “Kritis hadapi hoax”. Infokomputer, Maret 2017.

Departemen Agama RI. Al-Qur’an dan Terjemahnya. Jakarta: Departemen Agama

Hanafiyah, F. (2018). Literasi Lintas Kurikulum Dalam Pembelajaran Bahasa Indonesia Pada Sekolah Menengah Kejuruan. BIBLIOTIKA : Jurnal Kajian Perpustakaan dan Informasi, 1(2), 41-47.

Hernon, Peter. 1995. "Disinformation and Misinformation through the Internet: Findings of an Exploratory Study". Government Information Quarterly, volume 12, number 2, pages 133-139. JAI Press. ISSN 0740-624X

Indonesia. UNDANG-UNDANG REPUBLIK INDONESIA NOMOR 11 TAHUN 2008 TENTANG INFORMASI DAN TRANSAKSI ELEKTRONIK. Jakarta: DPR RI. 2008.

Katerattanakul, Pairin dan Siau, Keng. "Measuring Information Quality of web siter: Development of an Instrument". Proceeding ICIS '99 Proceedings of the 20th international conference on Information Systems. 1999. Pages 279-285

Kandari, Jaikrit. 2010. "Information Quality on the World Wide Web: A User Perspective". Industrial and Management Systems Engineering -- Dissertations and Student Research. Paper 16.

Keshavarz, Hamid. 2014. "How Credible is information on the Web: Reflection on misinformation and disinformation”. Infopreneurship Journal, 2014, Vol.1, No.2

Koswara, E. 1998. Dinamika Informasi Dalam Era Global. Bandung: Remaja Rosdakarya

Lestari, A. D. (2017). Menentukan Skala Prioritas Sistem Informasi Layanan Opac Studi Kasus Di Badan Perpustakaan Umum Dan Arsip Daerah Kabupaten Tulungagung. BIBLIOTIKA: Jurnal Kajian Perpustakaan Dan Informasi, 1(1), 81-90. https://doi.org/10.17977/um008v1i12017p081 
Mahany, Andry Trysandy. Pengguna LINE di Indonesia naik hingga 200 persen. https://www.brilio.net/gadget/pengguna-line-di-indonesia-naik-hingga-200-persen-1609031.html (diakses Februari 2017)

Mala, Jana and Cerna, Lubica. Information quality Its dimension and the basic criteria for assessing information quality. www.mtf.stuba.sk/docs/doc/casopis_Vedecke_prace/SN/Mala_Cerna.pdf (Diakses pada Januari 2017)

Meek, Scott W. et al. 2013. "Deception and the misinformation effect: an event-related potential study". International Journal of Psychophysiology. 87(2013) 81-87

Miller, Holmes. 1996. "The Multiple Dimensions of Information Quality". Information Systems Management, 13 (2): 79-82. doi:10.1080/10580539608906992.

Mozilla. Mozilla Web Literacy Map v1.1.0. https://learning.mozilla.org/en-US/web-literacy

Mursyidah, Dian. dan Salim, Agus. 2012. "Dakwah melalui media siber: analisis pesan dakwah dalam website Dakwatuna.com". Media Akademika, vol. 27. No.4. http://ejournal.iainjambi.ac.id/index.php/mediaakademika/article/view/167/150

Nasicha, Dina. 2016. “ Makna Tabayyun Dalam Al-Quran: Studi perbandingan antara tafsir Al-Muyassar dan tafsir Al-MIsbah”. Skripsi., UIN.

Nata, Abuddin. 2002. Tafsir Ayat-ayat Pendidikan(Tafsir Al-Ayat Al-Tarbawiy), Jakarta: PT Raja Grafindo Persada .

Nazir, M. 2003. Metode Penelitian. Jakarta: PT. Ghalia Indonesia

Nur Baits, Ammi. Siapakah orang fasik?. https://konsultasisyariah.com/11768-siapakah-orang-fasik.html

Shihab, M. Quraish. 2009. Tafsir Al-Misbah, Jakarta: PT Lentera Hati

Tanaka, Katsumi, et al. "Evaluating credibility of web information". Proceeding ICUIMC '10 Proceedings of the 4th International Conference on Uniquitous Information Management and Communication. 2010. Article No. 23

Wahyudi, M. Zaid. "Memilah informasi di era digital”. Kompas, 13 April 2015.

Wang, R. dan Strong, D. 1996. "Beyond Accuracy: What Data Quality Means to Data Consumers". Journal of Management Information Systems, 12 (4): 5-34. 